\title{
What is the Future of the Global Economy?
}

\begin{abstract}
The article addresses issues related to the current stage of globalization. It analyzes the main causes of the economic and social anti-liberal counter-revolution and emphasizes its influence on the newly emerging shape of the global economic order. The financialization of the world economy, which is largely the result of uncontrolled financial markets, as well as speculative bubbles that are very painful for the population, has contributed, among other things, to the questioning of the development model based mainly on markets, without proper regulatory and control support from the state. If there is an ever-growing conviction that at the current stage of economic development, globalization based on neo-liberal principles should be thoroughly thought through, then what direction should the corrections or changes in the current state take. The author shares the viewpoint of Joseph E Stiglitz that the European Union is such an organization that can and should become a reference point for economic and social integration, and thus for the newly emerging global economic order. Increasing the integration of the political, regulatory, and stimulating role of the state in the economy does not mean substituting market competitiveness with protectionism and economic nationalism.
\end{abstract}

Keywords: Globalization; Anti-liberal Counter-revolution; Development Paradigm; European Union; New Structural Economics.

\section{Introduction}

The large-scale intervention of the final lenders (central governments and central banks) has ended the escalation of the loss of financial liquidity by the vast majority of the world's main economic and financial entities (commercial banks, investment funds, insurance funds, etc.). It caused an increase of optimism in the global economy. According to the latest forecasts by the Organization for Economic Cooperation and Development (OECD), the global economy will grow in 2018, but also in 2019, by 3.9 percent, which is the highest since 2011. That acceleration of pace will mainly result from the revival in trade 
and investments ${ }^{1}$. However, the opinion of one of the most prestigious British economic newspapers seems to be characteristic as it predicts that "globalization has survived many things, but the invasion of mercantilist populism may be the biggest challenge for decades. The year 2018 is not disastrous for international trade, but it may turn out to be a year of dreadful waiting for the outbreak of trade wars" (Financial Times, 2018).

There is a serious concern that more and more governments, recognizing the weaknesses of the current stage of globalization, may overprotect their economies from foreign competition, in the hope this will bring good economic and social results.

There is also a growing question about the role of the state and the market in economic processes. The previous global financial crisis has placed in the center of attention, among others, the issue of controlling international capital flows. Now, in particular in the case of emerging economies, there arises the question of the appropriateness of introducing specific tools for controlling capital transfer (Wojtyna, 2017), but this topic deserves separate treatment.

\section{The Economic and Social Causes of the Anti-liberal Counterrevolution}

One of the most important analytical centers in the world - The Economist Intelligence - believes that the potential problem lies also in the fact that current and future activities of President Donald Trump are in line with the current trend in the global economy. Namely, more and more countries are openly talking about closing their economies to foreign competition or at least concentrating more on using their own resources.

However, the problem is much more serious and deeper. In the book Nowy Pragmatyzm kontra Nowy Nacjonalizm (New Pragmatism versus New Nationalism), Grzegorz W. Kołodko aptly notes that the socio-economic phenomena and processes currently occurring in the world are becoming more complicated and conflict triggering (Kolodko and Koźmiński, 2017). He is ready to attribute them largely to social and economic imbalances, but also to demographic processes and threats to the human natural environment. In his opinion, these phenomena are not yet sufficiently explained by economic sciences, because - as he claims - the current schools of economics, especially

1 https://www.ppr.pl/wiadomosci/oecd-gospodarka-swiatowa-w-2018-i-2019-r 
mainstream economics, turn out to be outdated, inadequate, ill-prepared to tackle new problems so in this respect something new should be looked for (Kolodko and Koźmiński, 2017, p. 11).

Andrzej K. Koźmiński believes that "people all over the world are beginning to aspire to an ever-higher level of well-being, and while in past centuries they humbly accepted their fate, so nowadays there is no such consent and there is a potential for violent protest" (Kołodko and Koźmiński, 2017, p. 11).

This view corresponds to the main conclusions of the study of Thomas Piketty, who in his book entitled Capital in the Twenty-First Century states that "the dynamics of private capital accumulation inevitably lead to the concentration of wealth in ever fewer hands..." (Piketty, 2015, p. 11). Piketty concludes: "When the rate of return on capital exceeds the rate of growth of output and income, as it did in the nineteenth century and seems quite likely to do again in the twenty-first, capitalism automatically generates arbitrary and unsustainable inequalities that radically undermine the meritocratic values on which democratic societies are based." (Piketty, 2015, p. 11). He doubts that "the balancing forces of growth, competition, and technological progress lead in later stages of development to reduced inequality and greater harmony among the classes, as Simon Kuznets thought in the twentieth century" (Piketty, 2015, p. 11). In his research, Piketty rightly delves into history, because he wants to show the thesis that the American dream, or the promise of Western egalitarian capitalism, is not able to come true and nothing will change in the future. In this system, the rate of economic growth is always lower than the rate of return on capital invested. The entire society benefits from the growth, while from the profit - only the richest do (Pikety, 2015, p. 373).

Professor of European Studies at the University of Oxford, Jan Zielonka, in the book entitled Counter-Revolution: Liberal Europe in Retreat, tries to see the reasons that underlie the anti-liberal counter-revolution and the establishment of governments and political parties questioning the liberal version of democracy and market reforms based on the Washington Consensus (Zielonka, 2018). "Across Europe politics was increasingly presented as an art of institutional engineering and not as an art of political bargaining between the elites and the electorate. More and more powers were delegated to non-majoritarian institutions - central banks, constitutional courts, regulatory agencies - to make sure that reason rather than passion guided political decisions. Politics giving in to public pressure was considered irresponsible if not dangerous ... Citizens were to be educated rather than listened to" (Zielonka, 2018, p. 24).

This surprising diagnosis by a professor with liberal views, who, despite the aforementioned criticism, nevertheless believes in the revival of new liberalism, 
deserves to be quoted. We are dealing, at least on the European continent and in the United States, with clearly noticeable tendencies, which also translate into the character and architecture of the new economic and social order.

Dani Rodrik has already claimed that there is a conflict between democracy, unlimited economic globalization, and autonomy or the sovereignty of states. He argued that it is impossible for these three political goals to coexist at the level of the nation state.

The British weekly The Economist (The Economist, 2018) in the analysis of Why democracy dies recalled that in 1941 there were only few democracies in the world. By 2000, however, only 8 countries had no free elections. In studies carried out in 38 countries, 4 out of 5 persons preferred the democratic system. It was then that in 1989, Francis Fukuyama claimed "the end of history" - democracy will win - the system of liberal democracy will be universal, and the market economy will be impregnable (Fukuyama, 2009).

Today, as the weekly "The Economist" observes, we are facing a retreat from democracy. The magazine tries to cite the examples that support that statement and rationalize them. The process of this retreat clearly accelerated during the financial crisis in 2007-2009, and with the ongoing destabilization caused by migration and intensification of armed conflicts:

1) social feelings have grown that the democratic elites cannot fully or completely overcome the crisis and political and social tensions. The biggest financial crisis since the depression of the 1930s, the growing debt crisis in Europe, billions of public money transferred to the rescue of banks, deepening financial inequalities, all that frightened and frustrated millions of people;

2) there have not been many new strong leaders with democratic convictions like Konrad Adenauer, Margaret Thatcher and the founding fathers of the European Union. Instead, there were strong leaders (strongmen) who undermined confidence in liberal democracy and the current elite.

On the other hand, the new leaders (strongmen) have proposed:

- dismantling or limiting existing institutions and democratic customs;

- creating and searching for the enemy (Donald Trump considers the democratic and liberal elites as the main enemy). In return, there was a search for new elites, but those that are loyal, have qualifications, do not question the authority of the leader (also from the intellectual side). The Islamic elites, in turn, got scared of the growing role of the new secular elite - though the attack in Turkey was unsuccessful, however, it was a sign of threat to their position; 
- a new economic policy that refers to the concept of economic sovereignty and the otherwise defined national interest in the conditions of globalization processes.

\section{Questions Marks Over the International Order}

All the above considerations also lead to placing question marks over the current order in the world, in particular over the economic model. Until recently, the development paradigm was based on the aforementioned Washington consensus. It grew not only from scientific research but also from real trends occurring in the globalization process. These megatrends in the global economy are first and foremost: deregulation, liberalization, privatization, and integration. These four main tendencies, occurring in the world economy, have become the basic canon of the economic policy of many countries.

The basic guidelines of the consensus for economic policy underwent certain modifications over time, but their main core remained unchanged. In the global economy they have become a kind of developmental pattern for many countries with varying degrees of economic and social advancement. The moment of breakthrough verifying the findings of the consensus became the unexpected, both in scale and size, global financial crisis in 2007-2009. Certain theoretical assumptions of economic theories based on faith in automatic repair mechanisms of the free market failed to work. Moreover, the system, devoid of mechanisms of regulation, began to "produce" various kinds of distortions. The "errors and distortions" that appeared on the financial markets turned out to be particularly severe for the economy as well as ordinary citizens (Nowak, 2013). There were also growing social and political problems, which were previously written in this dissertation. The Washington Consensus, which grew out of neoliberal theories, was seriously questioned.

Nevertheless, unambiguously negative assessments of the consequences of its implementation are also unjustified. Examples of countries can also be found that, implementing these assumptions, experienced the internationalization of their production and distribution, transfer and import of modern technologies, IT revolution, development of new markets, etc. Economic policy, based on consensus, has become an important element of the systemic transformation in so-called emerging economies, including Poland.

However, the uncritical faith in the automatic repair mechanisms of the "free market" did not work, something that, as mentioned, the global financial 
crisis (2007-2009) showed in particular, and the effects of it - as it seems - haven't been definitively and permanently overcome. The financialization of the world economy, which is largely the result of uncontrolled financial markets, or speculative bubbles that are very severe for the societies, have contributed, among others, to the questioning of the development model mainly based on markets, without proper regulatory and control support from the state. The criticism of the model, which is based on neo-liberal principles, can be accompanied by all their other consequences: frustrations and social inequalities, political and ecological threats, which were described earlier.

\section{Characteristics of New Globalization Trends}

The considerations should be preceded by the general characteristics of new trends in the economies of the most important countries in the world and the consequences of new phenomena in the globalization process.

- The technological revolution is progressing faster. Collecting and storing huge amounts of information for analytical purposes in various fields has been practiced for a long time. Today, however, the rapid growth and availability of data (big data), and at the same time their programmed selection, lead to obtaining qualitatively new opportunities. Linking and comparing relationships, hierarchies and various interconnections, collecting and selecting data from various sources, in particular in the economic sphere, opens up new opportunities for making quick and more reliable decisions and changes in business strategies. The largest transnational corporations are benefiting from this technological revolution in the first place. They have the fastest resources to match, clean up and transform data in different systems, also to gain a competitive advantage in the global market.

- In many countries (e.g. China, India, Israel) we observe a rapid shift from imitative development to development based on innovation. This leads to bigger disputes and even conflicts, e.g. regarding the observance of copyright.

- The financial crisis of 2007-2009 has changed for good the development dynamics of traditional and newly emerging economic powers. The Asian continent is becoming one of the most important centers of the global economy. And, what is also very important - the emergence of new economic powers is not based solely on neo-liberal principles. Even the International Monetary Fund questioned the main assumptions of the Washington Consensus. 
- More and more ruthless competition on the global market takes place in a situation where natural resources on Earth are running out. But there are also opinions that even more dangerous in the long run is the lack of common concern for the protection of the natural environment and disputes over the climate policy.

- The division into beneficiaries and outsiders of modern globalization is deepening. As mentioned earlier, inequalities are growing, putting into question the basic values on which modern societies are based. It triggers rebellion and growing opposition to the practices of globalism and its uncritical defenders.

- All the aforementioned phenomena contribute to the emergence of economic nationalisms appearing to various extents in many places, and to the conviction that in the face of weaknesses and imperfections of current trends on global markets, some forms of protectionism, restrictions on free trade should be introduced, even if potentially it might lead to an outbreak of trade conflicts. This approach also underlines the role of soft and hard power of individual countries - something that seems to be slightly underrated.

That "new nationalism", as the authors of the book call it (Kołodko and Koźmiński, 2017, p. 7) - "New pragmatism or new nationalism" is also characterized in the present conditions by "the revival of aggressive attitudes, views and policies that seemed to have expired once and for all after the horrific experiences of two world wars". Thus, in the global competition of an economic nature, the importance of foreign policy returns, which assumes a combination of soft and hard power (incl. political and manipulative factors) as important elements that effectively protect and strengthen the national interest.

\section{Globalization, But What Kind?}

If there is an ever-growing conviction that at the current stage of economic development, globalization based on neo-liberal principles should be thoroughly reconsidered, then what direction should the corrections or changes in the current state take? Is there a realistic concept to take advantage of the irreversibility of the globalization process with its positive results, but for an increasing number of countries in the world? And at the same time, how should the evident weaknesses and perversions, resulting in a growing dangerous social degradation and rebellion of many societies, be minimized? 
Someone who, in only one area, will effectively design and control the element and strength of contemporary markets, including primarily financial markets, and thus significantly change the processes and vectors of globalization, will deserve the Nobel Prize.

However, it is at least advisable not to make any more mistakes, as it is not worthwhile to support those scenarios of changes that may potentially create new threats, and maybe also bring new, serious conflicts. Attempts to resolve the contradictions of natural interests of corporations or states through forms of individual protectionism, the policy of imposing tariffs, replacing market competitiveness, conducting aggressive political strategies, replacing the mechanisms of transnational negotiations and arrangements, will most likely lead only to the return of national egoisms.

Meanwhile, in the global economy, where there is also objective competition and rivalry for national interests, nation states are doomed to failure, because through real danger of isolationism or separation, these countries have much less opportunities to realize their interests. This applies even to such powerful and leading countries as the United States. Even if until quite recently this seemed impossible.

Increasing the regulatory and stimulating role of the state in the economy - as a necessary postulate to reduce unfavorable processes on the global market - does not mean choosing to limit integration and global trade or the attempt to replace market competitiveness through protectionism and economic nationalism. With all its shortcomings, the integration and free flow of technology, capital, and workforce is one of the strongest development impulses on the scale of countries, regions and the world. "A bureaucratized almighty state is just as unacceptable as a total free market" (Nowak and Ryć, 2017, p. 81).

\section{Where to Look for Additional Development Impulses?}

If the attempt to replace the existing order through various forms of hegemony of its main actors, and not through attempts at consensus, would be implemented, then the global economy would have become an even more serious cause of global conflicts. Globalization processes should therefore be subject to greater control by transnational organizations or through legal and other regulations that will be agreed by consensus or at least by most states. It will be extremely difficult to accomplish. Realistically assessing, the hope that 
global "new pragmatism" is possible on the part of major actors in the global economy seems to be in vain. Therefore, it is worth to look for solutions that are proven not so much in the global context as in the regional one.

\subsection{Let Us Look at the European Union}

The European Union is such an organization that can and should become a reference point for economic and social integration, and thus more broadly - for global order.

Nobel Prize winner, Joseph E. Stiglitz, in the book entitled The Euro. How a Common Currency Threatens the Future of Europe (Stiglitz, 2017), shows convincingly how the current solutions, especially in the euro zone, contribute to creating discrepancies rather than cohesion in the European community and asks whether Europe can develop without the euro. Unlike most American economists, Stiglitz positively considers how to create a euro zone that will work. He emphasizes his hope that what he proposes will contribute to the implementation of solutions that will provide the continent with prosperity and "support our solidarity". However, he also assumes that if it is impossible to carry out the reforms that he proposes, "Europe must decide to abandon the euro in order to save the project much more important - a political integration project, important not only for the Old Continent, but for the whole world" (Stiglitz, 2017, p. 69).

Joseph Stiglitz is convinced that if the common currency is to work, then "we need more Europe". He specifies that he does not right away want a federation in the shape of the United States, where two-thirds of all public spending takes place at the central level, but definitely an increase in the current level of integration. A more efficient Common Market and free migration require "more Europe". All the more so the common currency requires "more Europe" (Stiglitz, 2017, p. 69). The plans of reforms and thorough changes proposed by him, which are supposed to lead to the saving of the euro zone and the European project, deserve a separate treatment, because the euro zone countries without further reforms, but without acceptance for them, will still be exposed to deep divergences and conflicts.

J. Stiglitz, however, looks at the European Union and the euro zone more broadly - in the context of globalization. He writes that "there is still a debate going on; what are the conditions for successful globalization. What to do if it does not proceed as we would like it to do? What are the costs and who benefits

from it? Who is losing? In this sense, Europe's successes and failures are a good lesson for the future - both in terms of regional integration and this learning at 
the global level ...". Stiglitz, on the example of the European Union, emphasizes that "economic integration (globalization) will fail if it leaves political integration behind. Therefore, there is a growing need for collective actions - so as to be sure that the mutual benefits will be greater than the damage caused to each other" (Stiglitz, 2017, p. 69). With all reservations regarding the current stage of the functioning of the European Union and the euro zone, Joseph E. Stiglitz, treats the European Union as an important project, important not only for the Old Continent. As he emphasizes, "the success of the European project lies not only in the interest of Europe".

European regionalization can be seen as an important element of globalization. However, the UK's exit from the EU and the incompletely overcome effects of the financial crisis of 2007-2009, or the shortcomings of the euro zone, raise certain questions about following the European development model. All the more so that new Asian economic powers emerged that made the Asian continent one of the most important centers of the global economy and thus changed the vectors of globalization.

\section{Conclusions}

The benefits of integrating the Polish economy with the world economy within the World Trade Organization (WTO) and the European Union, and participating in the globalization process also entailed some negative phenomena, which should be treated as costs. However, the overall balance of benefits outweighs the costs.

As a country in the process of catching up with the most developed countries, Poland is also reviewing widely accepted economic theories. It looks more closely at and draws practical conclusions from the experience of those countries that have achieved economic success, not following the classic path of neoliberalism. However, it pays much more attention to economic development as a process of structural changes and industrial policy, which is an important tool for setting priorities in the use of limited resources. Hence the interest of Polish authorities in the doctrine of the New Structural Policy, of which one of the most important authors is the Chinese economist Justin Yifu Lin. The essence of this doctrine lies in the fact that the factor that determines the success of development is the state that enables this development by pursuing an appropriate industrial policy. As Justin Y. Lin points out, the economic development is a process of structural change. The desired industrial policy should therefore be aimed at 
facilitating the development of industries with hidden competitive advantages, but it should also help companies to get out of those industries in which the country loses its comparative advantage. In a competitive market, governments should reward enterprises for adding value to the public domain, developed by the first initiators in new industries - those in which the country has hidden comparative advantages - but also to provide and coordinate support for hard and soft infrastructure to reduce transaction costs (Lin, 2017, p. 199-200).

In certain segments of the economic policy, Poland is currently using the New Structural Economics guidelines, in particular through a more active role of the state, removing investment barriers to make up for technological delays in many important sectors of the economy. Under conditions of the global economy, Poland wants to free and activate the existing growth potential, and thus achieve developmental success. Therefore, it is looking for solutions that will allow it to find itself in the changing realities of the global economy in the most beneficial manner.

\section{References}

De Grauwe, P. and Ji, Y. (2018). Inżynieria finansowa nie ustabilizuje niestabilnej strefy euro. Obserwator Finansowy, 19 April.

Financial Times. (2018). Komentarz redakcyjny, 28.06.2018.

Fukuyama, F. (2009). Koniec historii. Kraków: Wydawnictwo Znak.

http://globaleconomy.pl.

https://www.ppr.pl/wiadomosci/oecd-gospodarka-swiatowa-w-2018-i-2019-r.

Kołodko, G.W. and Koźmiński, A.K. (2017). Nowy Pragmatyzm Kontra Nowy Nacjonalizm. Warszawa: Wyd. Prószyński i S-ka.

Krugman, P. (2008). The Return of Depression Economics and the Crisis of 2008. December. USA: W.W. Norton\&Company Inc.

Lin, J.Y. (2017). Nowa Ekonomia Strukturalna dla gospodarek doganiających. In: J.Y. Lin, A.Z. Nowak (eds), Nowa Ekonomia Strukturalna wobec krajów mniej zaawansowanych. Warsaw: Wydawnictwo Naukowe Wydziału Zarządzania Uniwersytetu Warszawskiego.

Nowak, A.Z. (2013). Współczesny świat w erze turbulencji. In: J. Bogdanienko, W. Piotrowski (ed.), Zarzadzanie: tradycja i nowoczesność. Warsaw: PWE.

Nowak, A.Z., Wojtaszczyk, K.A. and Zamęcki, Ł. (2016). Poland in the European Union. Coleccion Universidad 8. Madrid: Schedas.

Nowak, A.Z. and Ryć, K. (2017). Polityka $w$ regionach $w$ warunkach globalizacji. Warsaw: Wydawnictwo Naukowe Wydziału Zarządzania Uniwersytetu Warszawskiego.

Nowak, A.Z. i Lin, J.Y. (2017). New Structural Economics for Less Advanced Countries. Warsaw: Wydawnictwo Naukowe Wydziału Zarządzania Uniwersytetu Warszawskiego.

Nowak, A.Z. and Taplin, R. (2010). Intelectual Property, Innovation and Management in Emerging Economics. London: Routledge. 
Piketty, Th. (2015). Kapitat w XXI wieku. Warsaw: Wydawnictwo Krytyki Politycznej.

Stiglitz, J.E. (2006). Making Globalization Work. USA: W.W. Norton\&Company Inc., September.

Stiglitz, J.E. (2008). The Triumphant Return of John Maynard Keynes. Guatemala Times, 5 December.

Stiglizt, J.E. (2017). Euro. W jaki sposób wspólna waluta zagraża przyszłości Europy. Warsaw: Wydawnictwo Krytyka Polityczna.

The Economist. (2018). Why the democracy dies, 16 June, No. 12.

Wojtyna, A. (2017). Nowa faza dyskusji o kontroli międzynarodowych przepływów kapitału. Gospodarka Narodowa, November - December.

Wojtyna, A. (2008). Współczesna ekonomia - kontynuacja, czy poszukiwanie paradygmatu. Ekonomista, 1.

Zielonka, J. (2018). Kontrrewolucja. Liberalna Europa w odwrocie. Warsaw: PWN. 